\title{
IMPACT OF EIGHT DIMENSIONS ON THE BUSINESS OF SPECIALTY COFFEE SHOPS
}

\author{
DOI: 10.17261/Pressacademia.2019.1023 \\ RJBM-V.6-ISS.1-2019(7)-p.79-87
}

Chiu-Chi Wei ${ }^{1 *}$, Chin-Hsin Chiu ${ }^{2}$, Suz-Tsung Wei ${ }^{3}$, Chiou-Shuei Wei ${ }^{4}$

$1^{*}$ Chung Hua University, Industrial Management, 707, Sec.2, WuFu Rd., Hsinchu, Taiwan. a0824809@gmail.com , ORCID: 0000-0002-9433-9114

2 Chung Hua University, Ph.D. Program of Technology Management, 707, Sec.2, WuFu Rd., Hsinchu, Taiwan. professorcoffee35@gmail.com, ORCID: 0000-0003-1842-5747

3 Fu Ren Catholic University, Business Administration, 505, Zhongzheng Rd., Xinzhuang Dist., New Taipei, Taiwan. mba318@gmail.com, ORCID: 0000-0002-1641-158X

4 Lunghwa University of Science and Technology, Industrial Management, 300, Wanshou Rd., Taoyuan, Taiwan. 747964@gmail.com , ORCID: 0000-0001-5925-7490

Date Received: November 20, 2018

Date Accepted: February 26, 2019

To cite this document

Wei, C. C., Chiu, C. H., Wei, S. T., Wei, C. S. (2019). Impact of eight dimensions on the business of specialty coffee shops. Research Journal of Business and Management (RJBM), 6(1), p.79-87.

Permemant link to this document: $\underline{h t t p: / / d o i . o r g / 10.17261 / P r e s s a c a d e m i a .2019 .1023 ~}$

Copyright: Published by PressAcademia and limited licenced re-use rights only.

\section{ABSTRACT}

Purpose- The impacts of eight dimensions, including customer communication, customer relationship management, customer satisfaction, customer loyalty, strategy management, customer trust, and service quality, on the business of specialty coffee shops were investigated,

Methodology- A questionnaire was designed to collect the data from 197 valid respondents; Structural Equation Modeling (SEM) was utilized to analyze the data, and finally, Smart PLS was employed to validate the structural model.

Findings- Nine of the eleven hypothesized relationships were confirmed and supported, while two were not supported.

Conclusion- Results of this study can provide business owners of specialty coffee shops with valuable information and management implications.

Keywords: Brand image, strategy, customer relationship management, communication, customer loyalty, trust, service quality, customer satisfaction, specialty coffee shop.

JEL Codes: C39, C61

\section{INTRODUCTION}

Coffee is one of the most popular beverages around the world, and is the second largest valuable traded commodity after petroleum (Murthy \& Naidu, 2012). A lot of unique and specialty coffee shops have been opened in both rural and urban areas in Taiwan, and because of stiff competition, coffee shops have to perfect their service and quality to survive. Coffee business is dramatically growing globally, and statistics show that casual drink markets remain dominated by coffee shops. An overview of the recent decades on the global coffee sector reveals the largest growth (Kablan et al., 2017), and the figures show that the world coffee import data is increasing yearly, and that more people are enjoying specialty coffee globally (Han et al., 2018). Recently, specialty coffee shops have rapidly increased in various countries. In 2017, there was a $39.8 \%$ increase in the United Kingdom, $46 \%$ in America, $50 \%$ in Korea, and an astonishing growth of $61 \%$ in Taiwan. There is a projected $100 \%$ growth by 2020 (The Statistics Portal, 2018). Consequently, the competition in coffee shops promotes modernization of the coffee industry (Samoggia \& Riedel, 2018). 
Specialty coffee is quality coffee based beverages characterized by unique quality, incisive taste and personality to attractive customers. According to Shan et al. (2017), consumers greatly enjoy each coffee's exclusive aroma and flavor (Zapata et al., 2018), and are willing to pay for high quality (Kang et al., 2012). Additionally, coffee has been recognized as a beverage with positive effects on human health (Kim, 2016). Previous research has also discovered that coffee improves social and personal well-being within emotionally taxing occupations (Stroebaek, 2013). Furthermore, products offering customer value help promote the economy, enhance health and increase happiness (Chen \& Hu, 2010).

Based on the abovementioned background about specialty coffee industries, this study intends to explore the effects of eight dimensions on the business of specialty coffee shops, including customer communication, customer relationship management, customer satisfaction, customer loyalty, strategy management, customer trust, and service quality. This paper is composed of the following sections, the introduction, literature review, research method, research results and conclusion.

\section{LITERATURE REVIEW}

Coffee has enormous impact on globally lucrative beverage industries. Eight influential dimensions affecting the specialty coffee industry have been identified in different studies, including customer communication, customer relationship management, customer satisfaction, customer loyalty, strategy management, customer trust, service quality, and. brand image.

Customer communication is regarded as a complex construct that includes numerous apparatuses (Nadhar et al., 2017). Customer relationship marketing is helpful in eliciting customer value emanating from different origins, and thus contributes to successful strategic management (Lian \& Yoong, 2017). Managers need to connect with and maintain relationships with their current and future customers to adequately fulfill the roles of communication and promotion (Kotler, 2000). The issue is usually not whether to communicate, but rather when, where and how to communicate to drive brand value (Hsieh et al., 2018). Customer Relationship Management (CRM) has changed the approaches of coffee shop interactions with current or potential consumers and influenced purchase behaviors by using customers' historical data to improve business relationships with customers (Trainor et al., 2014). CRM programs intertwine script actions in communication pathways rather than promoting rich communication and facilitating emanating responses (Mitussis et al., 2006). It influences corporate culture, corporate identity, and employee's needs (Triznova et al., 2015). It delivers superior customer value and satisfaction with the goal of improving business relationships with customers (Soltani \& Navimipour, 2016). CRM mediates the relationship between service quality and customer satisfaction (Setiawan \& Sayuti, 2017). Customer satisfaction can be categorized into two types: transaction-specific satisfaction and cumulative satisfaction (Kim, 2016). While customer satisfaction influences repurchase intentions and behaviors, however, Setiawan and Sayuti (2017) stated that satisfied customers cannot always be expected to return or to spread positive word-of-mouth because they may have actually been looking for something different (Qu et al., 2012). Lian and Yoong (2017) further showed that it is impossible to measure customer satisfaction measured without considering fulfillment. Customer loyalty is the aptitude of buyers to purchase specific products, services, and brands inside coffee shops (Han et al., 2018). Customer satisfaction and loyalty are concerned with the importance of a purchaser's return, making of referrals, and provision of verbal advertisement (Verhoef, 2003). It points out customer satisfaction levels on customer loyalty (Tarak et al., 2014).

Strategic processes happen between businesses and their customers (Payne \& Frow, 2005). These processes affect all interactions and create long-term value with customers (Bull, 2003). This concept also distinguishes between customers seeking economy and those holding onto expectations (Terho, 2015). Trust involves having customer needs or wants met. Trust emanates from the honesty and reliability of the opposite party in question (Verhoef, 2003). It remains fundamental, and affects customer confidence in the coffee shop (Young \& Chiu, 2017). Service quality entails an assessment of expectations concerning service preference (Parasurman et al., 1985). Tangible service or satisfaction performance, a feeling that one party gives to the other, often results in actual ownership emotions (Setiawan \& Sayuti, 2017). This kind of service influences the customer satisfaction perceived in coffee shops, customers' loyalty and trust (Heri, 2017). Brand image is one of the important antecedents of buyer satisfaction and loyalty (Cailleba \& Casteran, 2009; Ring et al., 2015). Discussing the positive relationship between branding and satisfaction Chin and Newsted (1999) stated that when buyers favor the brand image, colors, name, logo, personality styles, interesting design of the store, they will develop loyalty. Terho et al. (2015) emphasized the influence of brand image on customer loyalty. Branding increases satisfaction and loyalty in coffee industries (King, 2017). Founded upon the relationship of theory and purpose, researchers have shown that the above eight dimensions' directly affect customers' thoughts. 


\section{RESEARCH METHOD}

Based on the literature review, we used an empirical study to explore the effects of brand image on various factors by analyzing the survey data to verify research hypotheses. To increase the validity of the research results of this study, a questionnaire was designed, pre-tested and modified. Structural equation modeling (SEM) was adopted for data analysis, and the validation of the structural model was achieved using Smart Partial Least Squares (Smart PLS) software.

The data collection was conducted for three months from January $1^{\text {st }}$ to March $31^{\text {st }}, 2018$, in specialty coffee shops including "Professor Coffee Shop", "Izzy Café", and "Specially tailored Coffee Shop" in Taiwan. During the survey period, 220 completed questionnaires were collected, and after removing 23 incomplete questionnaires, a total sample of 197 valid responses was obtained. Among the valid responses, 97 of them were from males and the other 100 were from females. The age of participant was diverse, from younger than 18 to older than 65 years old, and the percentages were $2.8 \%$ for younger than $18,15.2 \%$ for $18-24,27.8 \%$ for $25-34,27.0 \%$ for $35-44,14.8 \%$ for $55-64$, and $12.4 \%$ for above 65 . As for educational background, $5.5 \%$ of respondents had not finished high school, $30.5 \%$ were high school graduates, $47.5 \%$ had college degrees and $16.5 \%$ had master's or PhD degrees.

The questionnaire used the Likert 5-point scale from "1: strongly disagree" to "5: strongly agree", and Smart PLS was utilized to analyze the collected data. Smart PLS is a statistical technique of Structural Equation Model (SEM) using blocks, constructs and items to iteratively estimate factor loadings and path coefficients. Figure 1 illustrates the details.

Figure 1: Partial Least Square Model

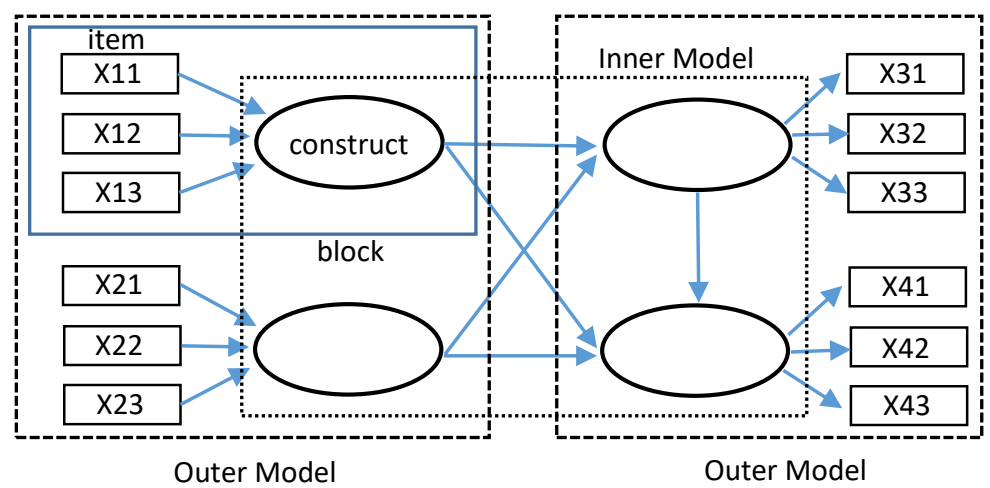

The factor loading denotes the correlation between item and construct, while the path coefficient implies the level of influence between two constructs. PLS uses two stages to validate the research model, the first stage is to examine the outer model, including convergent validity and discriminant validity, in other words, to validate if the questionnaire can support the proposed construct. The second stage is to examine the inner model to validate if the proposed hypotheses can be accepted, and discover the degree of accuracy of the interpretation of the construct. The implementation of PLS can be described as below in Figure 3 .

Figure 2: Example of PLS

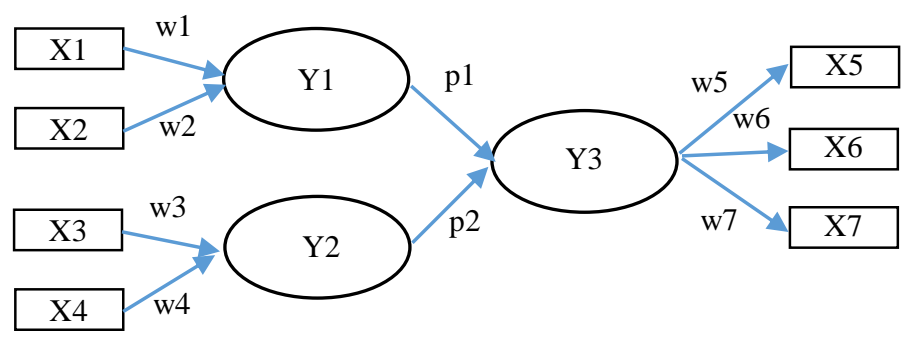




\section{Step 1: iteratively estimate the latent construct scores}

A construct must be measured by several items, therefore, PLS uses the following methods to assign a number to the construct.

1.1 Apply the regression method to estimate the latent construct scores for constructs $\mathrm{Y} 1, \mathrm{Y} 2$ and $\mathrm{Y} 3$.

1.2 Use the above scores to estimate the path coefficients $p 1$ and $p 2$, using various scheme such as centroid scheme, factorial scheme, structural or path weighting scheme, and this study used path weighting scheme.

1.3 Use latent construct scores obtained in Step 1.1 and path coefficients obtained in Step 1.2 to adjust latent construct scores.

1.4 Re-estimate factor loading w1 to w7.

Step 2: Utilize ordinary least square method to finalize the estimation of factor loading and path coefficients; in other words, to converge the estimate to a certain value.

The results of PLS can be verified using two values, the composite reliability and $\mathrm{R}$ square. The value of composite reliability must be greater than 0.7 (Hair et al. 2010), and the value of R square must be larger than 0.33 for average significance and 0.67 for substantial significance (Chin 1998), denoting the degree that the independent variable can explain the dependent variables. A value of 1 implies $100 \%$ and 0 implies $0 \%$.

Based on the research objective and research method, this study developed the following hypotheses to be validated:

H1: Communication positively influences customer relationship management.

H2: Communication positively influences customer satisfaction.

H3: Customer loyalty positively influences brand image.

H4: Customer relationship management positively influences customer loyalty.

H5: Customer relationship management positively influences customer satisfaction.

H6: Customer relationship management positively influences strategy.

H7: Customer satisfaction positively influences customer loyalty.

H8: Customer satisfaction positively influences customer trust.

H9: Service quality positively influences customer satisfaction.

H10: Strategy positively influences brand image.

H11: Customer trust positively influences customer loyalty.

\section{RESEARCH RESULTS}

This section describes the results of this study, and the effects of brand image on the business of specialty coffee shops are discussed by validating the hypotheses related to the eight dimensions. Table 1 lists the results, and the composite reliability indexes obtained were 0.952 for brand image, 0.944 for communication, 0.936 for customer loyalty, 0.957 for customer relationship management, 0.921 for customer satisfaction, 0.942 for service quality, 0.957 for strategy management, and 0.969 for customer trust respectively. The composite reliability must be greater than 0.8 ; therefore, it can be seen from the values that all of them are reliable (Hair et al., 2014).

The average variance extracted (AVE) for each factor are shown in Table 1. It is obvious that all values are far above 0.5 and were found to have convergent validity. The values of $\mathrm{R}$ square for each factor obtained were 0.665 for brand image, 0.664 for communication, 0.667 for customer loyalty, 0.573 for customer relationship management, 0.641 for customer satisfaction, 0.664 for service quality, 1.000 for strategy, and 0.521 for trust. It is apparent that all values are larger than the average level of 0.33 , and slightly below the substantial level of 0.67 . The above data indicated that the convergent validity and discriminant validity of the results were confirmed. Furthermore, the internal consistency or composite reliability can be verified using the composite alpha value, and it is obvious that all alpha values in Table 1 are more than 0.7 (Hair et al. 1998), indicating that a high degree of internal consistency was found in this study.

DOI: 10.17261/Pressacademia.2019.1023 
Table 1: Reliability and Validity

\begin{tabular}{lccccc}
\hline Dimensions & R Square & R Square Adjusted & $\boldsymbol{\alpha}$ & Composite Reliability & AVE \\
\hline Brand Image & 0.665 & 0.661 & 0.940 & 0.952 & 0.768 \\
Communication & 0.664 & 0.660 & 0.925 & 0.944 & 0.770 \\
Customer Loyalty & 0.667 & 0.662 & 0.908 & 0.936 & 0.784 \\
Customer Relationship Management & 0.573 & 0.570 & 0.940 & 0.957 & 0.848 \\
Customer Satisfaction & 0.641 & 0.636 & 0.893 & 0.921 & 0.700 \\
Service Quality & 0.664 & 0.660 & 0.922 & 0.942 & 0.764 \\
Strategy & 1.000 & 1.000 & 0.940 & 0.957 & 0.848 \\
Trust & 0.521 & 0.518 & 0.961 & 0.969 & 0.864 \\
\hline
\end{tabular}

\subsection{Pearson's Correlation Coefficients}

The Pearson's correlation coefficient is used to measure the statistical relationship between dimensions. It is a well-known method for measuring the correlation between variables of interest because it is based on the method of covariance. It provides information about the magnitude of the correlation and the direction of the relationship. Two variables are perfectly correlated when the Pearson's correlation coefficient is 1 ; highly correlated variables fall between 0.7 and 0.99 ; moderately correlated variables range between 0.4 and 0.69 ; modestly correlated variables fall between 0.1 and 0.39 ; weakly correlated variables are between 0.01 and 0.09; and 0 indicates no correlation at all. It can be seen from Table 2 that brand image is highly correlated with communication, customer loyalty, CRM, service quality, strategy and trust, because values of correlation coefficients are all greater than 0.7 ; similarly, communication is highly correlated with brand image, CRM, customer satisfaction, service quality strategy and trust; customer loyalty is highly correlated with brand image, CRM, strategy and trust; CRM is highly correlated with brand image, communication, customer loyalty, service quality, strategy and trust; customer satisfaction is highly correlated with communication, service quality and trust; service quality is highly correlated with brand image, communication, CRM, customer satisfaction, strategy and trust; strategy is highly correlated with brand image, communication, customer loyalty, CRM, service quality and trust; trust is highly correlated with brand image, communication, customer loyalty, CRM, customer satisfaction, service quality and strategy. Furthermore, strategy is perfectly correlated with CRM. Table 2 lists the details.

Table 2: Pearson Correlation Coefficients

\begin{tabular}{|c|c|c|c|c|c|c|c|c|}
\hline & BI & CO & $\mathrm{CL}$ & CRM & CS & SQ & $\mathbf{S}$ & $\mathbf{T}$ \\
\hline Brand image & 1.000 & & & & & & & \\
\hline Communication & 0.717 & 1.000 & & & & & & \\
\hline Customer loyalty & 0.778 & 0.666 & 1.000 & & & & & \\
\hline CRM & 0.772 & 0.757 & 0.807 & 1.000 & & & & \\
\hline Customer satisfaction & 0.679 & 0.776 & 0.631 & 0.699 & 1.000 & & & \\
\hline Service quality & 0.727 & 0.875 & 0.661 & 0.762 & 0.751 & 1.000 & & \\
\hline Strategy & 0.772 & 0.756 & 0.807 & 1.000 & 0.698 & 0.762 & 1.000 & \\
\hline Trust & 0.719 & 0.764 & 0.747 & 0.856 & 0.722 & 0.813 & 0.856 & 1.000 \\
\hline
\end{tabular}




\subsection{Structural Model}

A structural model is utilized to capture the linear regression effects of endogenous constructs upon one another, and it has the ability to specify the pattern of relationships among the constructs (Hair et al., 1998; Leohlin, 2998). A structural model was evaluated using three criteria: (1) path coefficients ( $\beta$ value), (2) path significant ( $p$ value), and (3) variance explain ( $R^{2}$ value). The bootstrap re-sampling method was used to test the statistical significance of each path coefficient. 500 iterations using randomly selected sub-samples were performed to estimate the hypothesized relationships. Figure 4 illustrates the structural model. All statistical tests were assessed at a $5 \%$ level of significance using two-tailed t-tests.

\section{Figure 3: Structural Model}

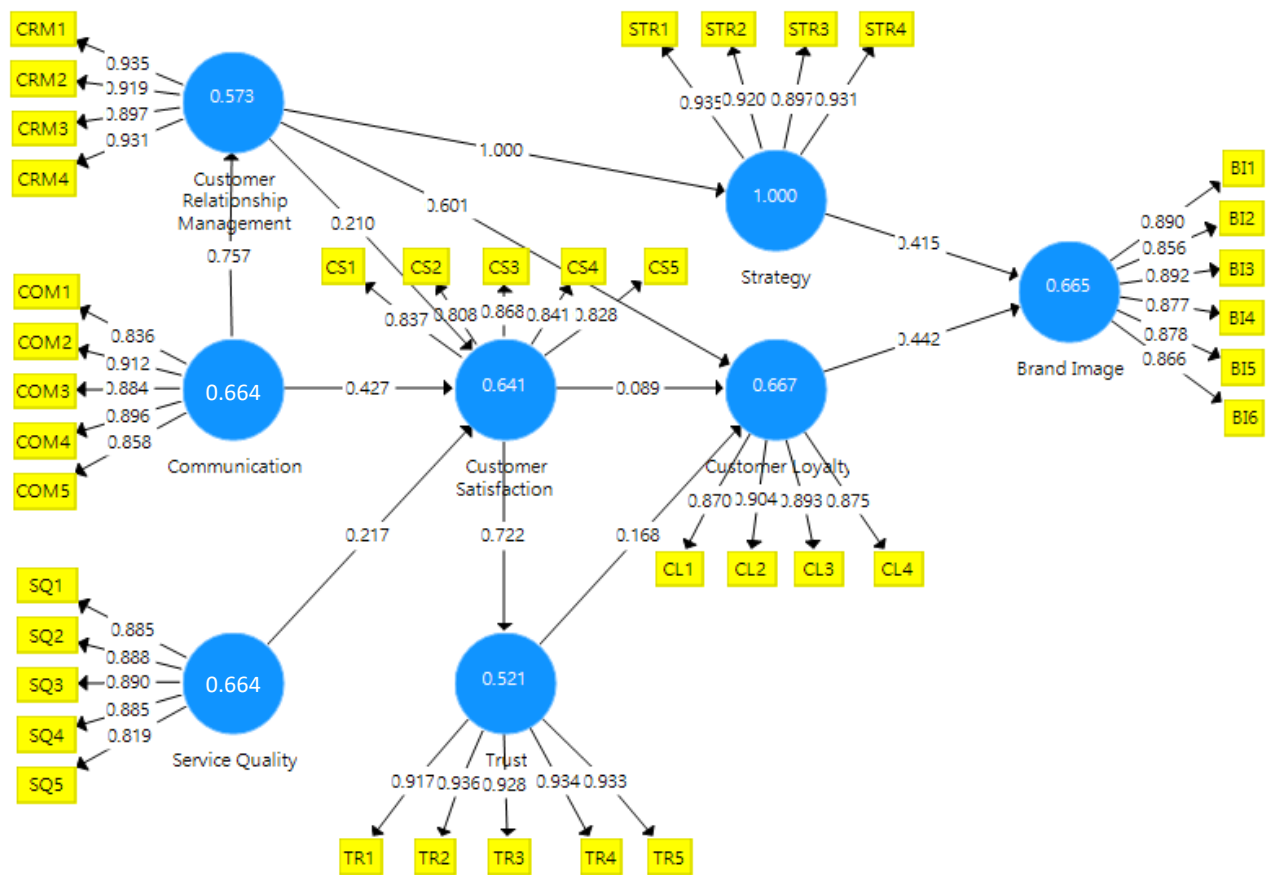

The results of the full model indicate that $57.3 \%$ of the variance in customer relationship management was explained by the model; $66.4 \%$ of the variance in communication was explained by the model; $66.4 \%$ of the variance in service quality was explained by the model; $64.1 \%$ of the variance in customer satisfaction was explained by the model; $52.1 \%$ of the variance in trust was explained by the model; $100.0 \%$ of the variance in strategy was explained by the model; $66.7 \%$ of the variance in customer loyalty was explained by the model; $66.5 \%$ of the variance in brand image was explained by the model. The evaluation criteria for validating the hypothesis was the use of $t$-values for each path loading, and the cut-off criteria was a t-value larger or equal to 1.645 for an alpha value of 0.05 (Hair et al. 2006).

Hypothesis $\mathrm{H} 1$ states that communication positively influences customer relationship management. Figure 4 shows that the hypothesized path for $\mathrm{H} 1$ was positive and significant $(\beta=0.757, \mathrm{p}<0.05)$, thus hypothesis $\mathrm{H} 1$ was supported.

Hypothesis $\mathrm{H} 2$ states that communication positively influences customer satisfaction. The hypothesized path for $\mathrm{H} 2 \mathrm{was}$ positive and significant $(\beta=0.427, p<0.05)$, thus hypothesis $\mathrm{H} 2$ was supported.

Hypothesis H3 states that customer loyalty positively influences brand image. The hypothesized path for H3 was positive and significant $(\beta=0.442, p<0.05)$, thus hypothesis H3 was supported.

Hypothesis $\mathrm{H} 4$ states that customer relationship management positively influences customer loyalty. The hypothesized path for H4 was positive and significant $(\beta=0.601, p<0.05)$, thus hypothesis $\mathrm{H} 4$ was supported. 
Hypothesis H5 states that customer relationship management positively influences customer satisfaction. The hypothesized path for $\mathrm{H} 5$ was positive and significant $(\beta=0.210, \mathrm{p}<0.05)$, thus hypothesis $\mathrm{H} 5$ was supported.

Hypothesis $\mathrm{H} 6$ states that customer relationship management positively influences strategy. The hypothesized path for H6 was positive and significant $(\beta=1.000, p<0.05)$, thus hypothesis $\mathrm{H} 6$ was supported.

Hypothesis $\mathrm{H} 7$ states that customer satisfaction positively influences customer loyalty. The hypothesized path for $\mathrm{H} 7 \mathrm{Has}$ not significant $(\beta=0.089, p>0.1)$, thus hypothesis $H 7$ was not supported.

Hypothesis $\mathrm{H} 8$ states that customer satisfaction positively influences customer trust. The hypothesized path for $\mathrm{H} 8$ was positive and significant $(\beta=0.217, p<0.05)$, thus hypothesis $\mathrm{H} 8$ was supported.

Hypothesis $\mathrm{H} 9$ states that service quality positively influences customer satisfaction. The hypothesized path for H9 was positive and significant $(\beta=0.722, p<0.05)$, thus hypothesis H9 was supported.

Hypothesis $\mathrm{H} 10$ states that strategy positively influences brand image. The hypothesized path for $\mathrm{H} 10$ was positive and significant $(\beta=0.415, p<0.05)$, thus hypothesis $\mathrm{H} 10$ was supported.

Hypothesis $\mathrm{H} 11$ states that customer trust positively influences customer loyalty. The hypothesized path for H11 was not significant $(\beta=0.168, p>0.1)$, thus hypothesis $\mathrm{H} 11$ was not supported.

\section{CONCLUSION}

This study explored the effects of eight dimensions on the business of specialty coffee shops, including customer communication, customer relationship management, customer satisfaction, customer loyalty, strategy management, customer trust, and service quality. An empirical study was applied to collect data using a questionnaire survey conducted in Taiwan, and structural equation modeling was adopted to analyze data, while Smart PLS was used to validate the structural model. Results of the research indicated that the all of the Cronbach's alpha values tracking the internal consistency of the scale exceeded 0.7; all factor loadings are far above the acceptable level of 0.5 ; all composite reliability values for each construct are greater than 0.7 ; all values of average variance extracted for each construct are also larger than 0.5 . Therefore, convergent validity and discriminative validity of this study were confirmed. Nine of the eleven hypothesized relationships were supported, except for the relationships between customer trust and customer loyalty, and between customer satisfaction and customer loyalty. This may be attributed to the fact that customer trust is just the prerequisite for visiting a specialty coffee shop, and not enough to induce customer loyalty. On the other hand, the reason that customer satisfaction did not contribute to customer loyalty may be due to the fact that customers visiting a specialty coffee shop may easily be attracted to other coffee shops providing new flavors and fashionable atmospheres. This would conform to the research results from previous studies. However, the conclusion of this study could be further explored using individual in-depth interviews to dive into the internal cognition of customers.

\section{REFERENCES}

Bull, C. M. (2003). Strategic issues in customer relationship management (CRM) implementation. Business Process Management Journal, vol. 9, no. 5, pp.592-602.

Cailleba, P., Casteran, H. (2009). A quantitative study on the fair trade coffee consumer. The Journal of Applied Business Research, vol. 25, no. 6, pp.31-46.

Chen, P. T., Hu, H. H. (2010). How determinant attributes of service quality influence customer-perceived value: An empirical investigation of the Australian coffee outlet industry. International Journal of Contemporary Hospitality Management, vol. 22, no. 4, pp.535-551.

Chin, W., Newsted, P. (1999). Structural Equation Modeling Analysis with Small Samples Using Partial Least Squares. In R. H. Hoyle (Ed.), Statistical Strategies for Small Sample Research. Thousand Oaks: Sage Publications. pp.307-341.

Hair, J., Hult, G., Ringle, C., Sarstedt, M. (2014). A primer on partial least squares structural equation modeling (PLS-SEM). SAGE Publications.

Han, H., Nguyen, H. N., Song, H., Chua, B. L., Lee, S., Kim, W. (2018). Drivers of brand loyalty in the chain coffee shop industry. International Journal of Hospitality Management, vol. 72, pp.86-97. 
Heri, H. (2017). Analysis the effect of service quality, customers value, customer satisfaction and customer trust on corporate image. Journal of Business and Management, vol. 19, no. 6, pp.38-46.

Hsieh, C. M., Chen, T. P., Hsieh, C. J., Tsai, B. K. (2018). Moderating effect of membership status on the quality-value-loyalty chain at museums. Social Behavior and Personality: an international journal, vol. 46, no. 1, pp.107-126.

Hulland, J. (1999). Use of partial least squares (PLS) in strategic management research: a review of four recent studies. Strategic Management Journal. vol. 20, no. 2, pp.195-204.

Kablan, S., Ftiti, Z., Guesmi, K. (2017). Commodity price cycles and financial pressures in African commodities exporters. Emerging Markets Review, vol. 30(C), pp.215-231.

Kang, J., Tang, L., Lee, J. Y., Bosselman, R. H. (2012). Understanding customer behavior in name-brand Korean coffee shops: The role of selfcongruity and functional congruity. International Journal of Hospitality Management, vol. 31, pp.809-818.

Kim, S. E., Lee, S. M., Kim, K. O. (2016). Consumer acceptability of coffee as affected by situational conditions and involvement. Food Quality and Preference, vol. 52, pp.124-132.

King, C. (2017). Brand management - standing out from the crowd: A review and research agenda for hospitality management. International Journal of Contemporary Hospitality Management, vol. 29, no. 1, pp.115-140.

Kotler, P. (2000). Marketing management: analysis, planning, implementation and control (seventh ed). New Jersey: Prentice Hall.

Lian, S. B. Yoong, L. C. (2017). The effectiveness of strategic relationship marketing: exploring relationship quality towards customer loyalty. International Business Research, vol. 10, no. 12, pp.159-166.

Likert, R. (1932). A technique for the measurement of attitudes. New York: Archives of Psychology.

Murthy, P. S., Naidu, M. (2012). Sustainable management of coffee industry by-products and value addition-A review. Resources Conservation and Recycling, vol. 66, pp.45-58.

Mitussis, D., O'Malley, L., Patterson, M. (2006). Mapping the re-engagement of CRM with relationship marketing. European Journal of Marketing, vol. 40, no. 5, pp.572-589.

Nadhar, M., Tawe, A., Parawansa, D. (2017). The effect of work motivation and entrepreneurship orientation on business performance through entrepreneurial commitments of coffee shops in Makassar. International Review of Management and Marketing, vol. 7, no. 1, pp.470-474.

Ou, W. M., Shih, C. M., Chen, C. Y., Tseng, C. W. (2012). Effects of ethical sales behaviour, expertise, corporate reputation, and performance on relationship quality and loyalty. The Service Industries Journal, vol. 32, no. 5, pp.773-787.

Parasurman, A., Zeithaml, A., Berry, L. (1985). A conceptual model of service quality and its implications for future research. Journal of Marketing, vol. 49, no. 4, pp.41-50.

Payne, A., Frow. P. (2005). A strategic framework for customer relationship management. Journal of Marketing, vol. 69, pp. 167-176.

Ringle, C., Wende, S., Beck, J. (2015). SmartPLS 3. Boenningstedt: SmartPLS GmbH.

Samoggia, A., Riedel, B. (2018). Coffee consumption and purchasing behavior review: Insights for further research. Appetite, vol. 129, no. 1, pp.70-81.

Setiawan, H., Sayuti, A. (2017). Effects of service quality, customer trust and corporate image on customer satisfaction and loyalty: An assessment of travel agencies customer in South Sumatra Indonesia. Journal of Business and Management, vol. 19, no. 5, pp.31-40.

Soltani, Z., Navimipour, N. (2016). Customer relationship management mechanisms: A systematic review of the state of the art literature and recommendations for future research. Computer in Human Behavior, vol. 61, pp. 667-688.

Stroebaek, P. S. (2013). Let's have a cup of coffee! Coffee and coping communities at work. Symbolic Interaction, vol. 36, no. 4, pp.381-397.

Tarak, P. (2014). Customer communication dimension of marketing mix- a review of gap between mutual fund investors' expectation and experience. Scholars Journal of Economics Business and Management, vol. 1, no. 5, pp.197-202.

Terho, H., Eggert, A., Haas, A., Ulaga, W. (2015). How sales strategy translates into performance: The role of salesperson customer orientation and value-based selling. Industrial Marketing Management, vol.45, pp.12-21.

The Statistics Portal. 2018, https://www.statista.com/statistics/270091/coffee-house- chains-ranked-by-revenue/

Trainor, K., Andzulis, J., Rapp, A., Agnihotri, R. (2014). Social media technology usage and customer relationship performance: A capabilitiesbased examination of social CRM. Journal of Business Research, vol. 67, no. 6, pp. 1201-1208. 
Triznova, M., Mat'ova, H., Dvoracek, J., Sadek, S. (2015). Customer relationship management based on employees and corporate culture. Procedia Economics and Finance, vol. 26, pp. 953-959.

Verhoef, P. C. (2003). Understanding the effect of customer relationship management efforts on customer retention and customer share development. Journal of Marketing, vol. 67, pp.30-45.

Young, L. J., Chiu, C. H. (2017). Is it feasible to use service quality, trust, and commitment management to determine customers' loyalty?. Transylvanian Review, vol. 20, pp. 5609-5619.

Zapata, J., Londoño, V., Naranjo, M., Osorio, J., Lopez, C., Quintero, M. (2018). Characterization of aroma compounds present in an industrial recovery concentrate of coffee flavor. CyTA - Journal of Food, vol. 16, no. 1, pp.367-372. 